\title{
Genes and post-term birth: late for delivery
}

\author{
William Schierding ${ }^{1}$, Justin M O'Sullivan ${ }^{1,2}$, José G B Derraik ${ }^{1}$ and Wayne S Cutfield ${ }^{1,2^{*}}$
}

\begin{abstract}
Background: Recent evidence suggests that prolonged pregnancies beyond 42 weeks of gestation (post-term births) are associated with long-term adverse health outcomes in the offspring.

Discussion: There is evidence that post-term birth has not only environmental causes, but also significant heritability, suggesting genetic and/or epigenetic influences interact with environmental cues to affect gestational length.

Summary: As prolonged gestation is associated with adverse short- and long-term outcomes in the offspring, further research into the underlying genetic and epigenetic causes of post-term birth could be of importance for improving obstetric management.
\end{abstract}

Keywords: Developmental biology, Embryonic and fetal development, Epigenetic research, Genetic research, Parturition, Post-term birth

\section{Discussion}

Preterm ( $<37$ weeks of gestation) and post-term ( $\geq 42$ weeks of gestation) births can be described as the two ends of the gestational age continuum. However, there is a disparity in the amount of research allocated towards these ends of the gestation spectrum. There is considerable research on the short- and long-term effects of preterm birth, as well as into its potential underlying causes [1]. In contrast, although post-term birth is relatively common worldwide [2], it has attracted far less attention [3]. However, recent evidence suggests that prolonged pregnancies beyond 42 weeks are associated with long-term adverse health outcomes in the offspring $[4,5]$. Importantly, there is evidence that while environmental stresses (e.g. malnutrition, insufficient myometrial contractility, intrauterine factors) play a large role in birth timing, over $25 \%$ of the variation in gestational age could be due to genetic effects [6]. More specifically, post-term birth has a large heritability, implicating genetics and/or epigenetics as contributing factors on gestational age [7-10].

\footnotetext{
* Correspondence: w.cutfield@auckland.ac.nz

'Liggins Institute, University of Auckland, Private Bag 92019, Auckland, New Zealand

${ }^{2}$ Gravida: National Centre for Growth and Development, Auckland, New
} Zealand

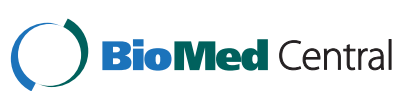

(c) 2014 Schierding et al.; licensee BioMed Central Ltd. This is an Open Access article distributed under the terms of the Creative Commons Attribution License (http://creativecommons.org/licenses/by/4.0), which permits unrestricted use, distribution, and reproduction in any medium, provided the original work is properly credited. The Creative Commons Public Domain Dedication waiver (http://creativecommons.org/publicdomain/zero/1.0/) applies to the data made available in this article, unless otherwise stated.
Post-term pregnancy: does an induced birth at 41 weeks count as a term pregnancy?

Post-term pregnancies are defined as those extending to or beyond 293 days ( $\geq 42$ weeks) from the first day of the last menstrual cycle (assuming a 28-day cycle) [11]. However, classification of post-term birth can be affected by pregnancy complications and clinical uncertainty of menstrual dating [3]. Further, there are pregnancies that would become post-term without obstetric intervention, such as induction at 41 weeks of gestation. Prior to active management to prevent prolonged pregnancy, $19-20 \%$ of pregnancies were post-term when women were allowed to progress naturally to spontaneous labour [12]. 'Best practice' guidelines recommend induction of labour at 41 weeks [13-15], but clinical management varies [16] and approximately $2-5 \%$ of babies are born after 42 completed weeks of gestation [17]. Although induction reduces acute risks [13], it does not alter the underlying genetic influence on prolonged gestation and the associated risk profile. Therefore, we argue that the study of post-term birth should include 'post-term potential', i.e. those births that would have occurred post-term if left unmanaged. The implementation of modern induction practices has seen the post-term rate fall to under $5 \%$ of total births. Therefore, based on Pekkanen et al.'s data [12], as many as $15 \%$ of total term births could be classified as 'post-term potential'. As such, $25 \%$ of routine inductions in low-risk pregnancies have prolonged pregnancy as the primary cause for induction $[18,19]$. 
What are the risks involved with post-term pregnancy?

Controversially, while epidemiological studies report a higher incidence of stillbirths and neonatal deaths in post-term pregnancies $[3,20]$, the only randomized controlled trial of intervention in prolonged pregnancy did not observe this difference [21]. Despite the controversy, post-term pregnancies are associated with many acute risks, including utero-placental insufficiency, fetal distress, non-progression, operative delivery (both operative vaginal and Caesarean), macrosomia, shoulder dystocia, low Apgar scores, and meconium aspiration [2,22,23]. Some studies have reported increased rates of post-partum haemorrhage following post-term delivery, especially in first pregnancies [24,25], but others have not observed this association [26]. These acute risks lead to increased morbidity and mortality when compared to term infants. Perinatal morbidity and mortality reach a nadir in births at term (37-41 weeks), increasing as gestational age deviates further from term, for both preterm and post-term pregnancies [27].

Beyond the acute risks, there is limited but emerging evidence that post-term birth can have long-term adverse effects $[4,5,28]$. An adverse fetal environment, including fetal growth restriction (which can occur with post-term birth), has been associated with hypertension [29] and obesity in adulthood [30]. Recent small studies have found that post-term birth is associated with features of the metabolic syndrome in mid-childhood and obesity in mid-adolescence $[4,5]$. In a cross-sectional study, Ayyavoo et al. found reduced insulin sensitivity, increased abdominal fat, impaired night-time blood pressure profile, and higher cholesterol levels in prepubertal children born post-term [4] with ultrasound confirmation of gestation. In a Swedish cohort followed longitudinally from birth to 16 years of age, post-term boys were found to be at higher risk of increased weight gain during childhood than term counterparts, leading to a greater incidence of obesity in adolescence [5]. As both of these are small studies, confirmation in larger cohorts is needed. Future research is necessary to better characterize the long-term health risks associated with post-term birth, informing and potentially influencing the obstetric management of prolonged pregnancies, particularly around the induction of labour.

\section{What epidemiological factors influence gestational age?}

There are a number of maternal risk factors that have been found to be associated with an increased risk of post-term delivery. These include first-time birth, maternal age over 30 years, obesity, poorer education, lower socioeconomic status, ethnicity, and dietary factors (e.g. high omega-3 or docosahexaenoic acid intake during the last half of pregnancy) [10,31-36]. The intake of common medicines can also affect gestational length, and low dose aspirin (a prostaglandin inhibitor) increases the likelihood of the pregnancy extending to post-term $[37,38]$.

\section{What is the evidence of a genetic effect on length of gestation?}

Genetic factors explained $25-40 \%$ of the variation in birth weight, fetal growth rate, and gestational age among twins [6]. Chaudhari et al. discussed evidence of a genetic predisposition for preterm birth including recurrence of prematurity in mothers or across families, as well as an increased incidence in certain ethnicities [39]. Similarly, a history of post-term delivery in a previous pregnancy was found to be the most important risk factor for post-term births [40,41], which was observed across a range of ethnicities [10]. Specifically, the risk of post-term delivery increases from $7.7 \%$, to $19.9 \%$, and $30 \%$ if the preceding birth was term, post-term, or extremely post-term (>44 weeks), respectively [42]. Moreover, sister pairs were more likely to experience post-term births than comparable brother pairs and brother-sister pairs, suggesting a possible transmission of genes down the motherdaughter line [7].

However, paternal genetics cannot be discounted, as the length of pregnancy differed by more than one week in families where there were different fathers between the index and subsequent birth [42]. This is further supported by the observation that if either the mother or father was born post-term, a child has an increased risk of also being post-term (49\% and 23\% greater, respectively), with further amplification of risk if both mother and father were born post-term [43]. When comparing maternal and fetal genetic influences on birth timing, fetal (26\%) and maternal (21\%) genetic factors explained almost half of the variation in gestational age, with environmental factors explaining the rest [7]. In twins, the heritability of post-term birth was estimated as $30 \%$, with the association being greater for monozygotic as opposed to dizygotic twins, further implicating an underlying genetic (as opposed to environmental) influence [8].

To date there have been no studies examining the effect of any specific common gene variant on prolonged gestation. At the opposite end of the gestational age spectrum, the major genetic determinants of preterm birth (that could be used to diagnose or prevent prematurity) also have yet to be found [44], as a meta-analysis of the available studies has failed to support earlier associations of preterm birth with genetic loci $[9,45,46]$. These studies have included several single-nucleotide polymorphisms (SNPs) located within the follicle stimulating hormone receptor (FSHR) gene [47], a functional SNP in the promoter of the Serpin Peptidase Inhibitor, Clade H (Heat Shock Protein 47), Member 1 (SERPINH1) gene [48], and the type 1 insulin-like growth factor receptor (IGF1R) gene [49]. However, it has been shown that inclusion of very preterm 
infants (22-34 weeks) in the analysis by Lunde et al. resulted in a decrease in the estimated genetic effect on gestation, suggesting that the genetics of preterm, term, and post-term births may differ [9]. Therefore, while these studies indicate that the entire gestational age spectrum is influenced by genetics, the specific genes associated with preterm and post-term births could be entirely different.

\section{Beyond genetics: what are the effects of epigenetics on gestational age?}

Transmissible phenotypes may not result solely from changes in the underlying DNA sequence. The epigenome can affect gene expression through DNA methylation, histone modification, chromatin folding, or small inhibitory RNA. Thus, alterations in DNA organization and packaging can enhance or suppress gene expression. For example, acetylation, phosphorylation, or methylation and ubiquitination of histone tails may alter the local chromatin structure, modifying the accessibility of the underlying DNA [50].

The epigenome is particularly susceptible to modification during gestation, neonatal development, puberty, and old age [51-54]. For instance, the relationship between epigenetics, aberrant nutrition, and lifetime metabolic dysfunction has been shown to have an effect in all of the above time periods, as well as having a trans-generational effect [55]. For post-term birth, the relevant time-period likely extends from conception until the end of gestation (i.e. the uterine environment), a period that is highly susceptible to epigenetic alterations [56]. For example, folate restriction in early gestation can cause global genome hypomethylation, restricting the ability of the fetus to impose cell-specific epigenetic modification [57].

Epigenetic changes in the fetus during pregnancy may affect length of gestation, with increased DNA methylation at three regions - near the nuclear factor I/X (CCAAT-binding transcription factor) (NFIX), Rap guanine nucleotide exchange factor (GEF) 2 (RAPGEF2), and methionine sulfoxide reductase B3 (MSRB3) genes - correlated with increased gestational age [58]. In addition, one study has found an association between LINE-1 DNA methylation (an inflammation marker) and preterm birth [59]. However, to date, no studies have examined potential epigenetic changes associated directly with post-term birth.

\section{Summary/future potential}

Prolonged gestation is associated with adverse shortand long-term outcomes in the offspring. Evidence for the heritability of post-term birth suggests an important connection between birth timing and underlying genetic factors. This creates an important distinction where the genes involved in 'post-term potential' could be an underlying risk factor for later-in-life disease, despite the 'best practice' to induce at 41 weeks. This raises two possibilities: 1) the underlying genetic causes of prolonged gestation (post-term potential) are directly responsible for the adverse long-term health effects in post-term individuals; or 2) prolonged gestation itself leads to physiological alterations and associated epigenetic changes, which in turn lead to long-term adverse effects. Either way, a better understanding of the genetic and epigenetic factors leading to and/or resulting from post-term birth could explain the mechanism leading to long-term health risks. By understanding mechanisms underlying causation (as opposed to just clinical symptoms or outcomes), these risk prediction profiles could then form guidelines for alternative obstetric management (discussed for preterm birth in [60] and [61]). In the future, tests for genetic risk of post-term birth could inform obstetric treatment options earlier in pregnancy, possibly identifying those at risk for (or protected from) post-term birth. This could provide a basis for pharmacogenomic interventions that shorten gestation tailored to the individual's genetic profile. Further research could also possibly lead to prolonged gestation being treated as a long-term effect, where both the acute and long-term consequences are taken into account and mitigated in a low-risk (to both baby and mother) and cost-effective manner.

Abbreviations

SNP: Single-nucleotide polymorphism.

\section{Competing interests}

The authors have no financial or non-financial conflicts of interest to disclose that may be relevant to this work.

\section{Authors' contributions}

WS was the primary author in drafting the manuscript. JMO and JGBD provided major revisions for important intellectual content and technical advice. WSC provided major revisions for important intellectual content and technical advice as well as supervision. All authors read and approved the final manuscript.

\section{Acknowledgments}

This work was supported by a University of Auckland Scholarship (WS), Gravida: National Centre for Growth and Development (WSC and JMO), and The Marsden Fund (JMO).

Received: 6 May 2014 Accepted: 29 September 2014

Published: 14 October 2014

References

1. Muglia $L$, Katz M: The enigma of spontaneous preterm birth. N Engl J Med 2010, 362:529-535.

2. Zeitlin J, Blondel B, Alexander S, Bréart G, PERISTAT Group: Variation in rates of postterm birth in Europe: reality or artefact? BJOG 2007, 114:1097-1103.

3. Norwitz ER, Snegovskikh W, Caughey AB: Prolonged pregnancy: when should we intervene? Clin Obstet Gynecol 2007, 50:547-557.

4. Ayyavoo A, Derraik JG, Hofman PL, Mathai S, Biggs J, Stone P, Sadler L, Cutfield WS: Pre-pubertal children born post-term have reduced insulin sensitivity and other markers of the metabolic syndrome. PLOS One 2013, 8:e67966. 
5. Beltrand J, Soboleva TK, Shorten PR, Derraik JG, Hofman P, Albertsson-Wikland K, Hochberg Z, Cutfield WS: Post-term birth is associated with greater risk of obesity in adolescent males. J Pediatr 2012, 160:769-773.

6. Clausson B, Lichtenstein P, Cnattingius S: Genetic influence on birthweight and gestational length determined by studies in offspring of twins. BJOG 2000, 107:375-381

7. Oberg AS, Frisell T, Svensson AC, lliadou AN: Maternal and fetal genetic contributions to postterm birth: familial clustering in a population-based sample of 475,429 Swedish births. Am J Epidemiol 2013, 177:531-537.

8. Laursen M, Bille C, Olesen AW, Hjelmborg J, Skytthe A, Christensen K: Genetic influence on prolonged gestation: a population-based Danish twin study. Am J Obstet Gynecol 2004, 190:489-494.

9. Lunde A, Melve KK, Gjessing HK, Skjaerven R, Irgens LM: Genetic and environmental influences on birth weight, birth length, head circumference, and gestational age by use of population-based parent-offspring data. Am J Epidemiol 2007, 165:734-741

10. Kistka ZA, Palomar L, Boslaugh SE, DeBaun MR, DeFranco EA, Muglia LJ: Risk for postterm delivery after previous postterm delivery. Am J Obstet Gynecol 2007, 196(241):e241-246.

11. World Health Organization: International Statistical Classification of Diseases and Related Health Problems, 10th revision. 2nd edition. Geneva: World Health Organization; 2004.

12. Pekkanen J, Xu B, Jarvelin MR: Gestational age and occurrence of atopy at age 31-a prospective birth cohort study in Finland. Clin Exp Allergy 2001, 31:95-102.

13. Caughey AB, Sundaram V, Kaimal AJ, Cheng YW, Gienger A, Little SE, Lee JF, Wong L, Shaffer BL, Tran SH, Padula A, McDonald KM, Long EF, Owens DK, Bravata DM: Maternal and neonatal outcomes of elective induction of labor. Evid Rep Technol Assess 2009, 176:1-257.

14. Doherty L, Norwitz ER: Prolonged pregnancy: when should we intervene? Curr Opin Obstet Gynecol 2008, 20:519-527.

15. National Institute for Health and Care Excellence: Induction of labour clinical guideline 70. http://www.nice.org.uk/guidance/CG70.

16. ACOG Committee on Practice Bulletins-Obstetrics: ACOG practice bulletin. Clinical management guidelines for obstetricians-gynecologists. Number 55, September 2004 (replaces practice pattern number 6, October 1997). Management of Postterm Pregnancy. Obstet Gynecol 2004, 104:639-646.

17. Creasy RK, Resnik R, lams JD: Creasy and Resnik's Maternal-fetal Medicine: Principles and Practice. 6th edition. Philadelphia, PA: Saunders/Elsevier; 2009.

18. Khireddine I, Le Ray C, Dupont C, Rudigoz RC, Bouvier-Colle MH, Deneux-Tharaux C: Induction of labor and risk of postpartum hemorrhage in low risk parturients. PLoS One 2013, 8:e54858.

19. AlHW, Li Z, Zeki R, Hilder L, Sullivan E: Australia's mothers and babies 2010. In Perinatal Statistics Series, Cat. no. PER 57, Volume 27. Canberra: AlHW; 2012.

20. Hilder L, Costeloe K, Thilaganathan B: Prolonged pregnancy: evaluating gestation-specific risks of fetal and infant mortality. Br J Obstet Gynaecol 1998, 105:169-173.

21. Hannah ME, Hannah WJ, Hellmann J, Hewson S, Milner R, Willan A: Induction of labor as compared with serial antenatal monitoring in post-term pregnancy. A randomized controlled trial. The Canadian Multicente Post-term Pregnancy Trial Group. N Engl J Med 1992, 326:1587-1592.

22. Bream EN, Leppellere CR, Cooper ME, Dagle JM, Merrill DC, Christensen K, Simhan HN, Fong CT, Hallman M, Muglia LJ, Marazita ML, Murray JC: Candidate gene linkage approach to identify DNA variants that predispose to preterm birth. Pediatr Res 2013, 73:135-141.

23. Olesen AW, Westergaard JG, Olsen J: Perinatal and maternal complications related to postterm delivery: a national register-based study, 1978-1993. Am J Obstet Gynecol 2003, 189:222-227.

24. Caughey AB, Stotland NE, Washington AE, Escobar GJ: Maternal and obstetric complications of pregnancy are associated with increasing gestational age at term. Am J Obstet Gynecol 2007, 196(155):e151-e156.

25. Buzaglo N, Harlev A, Sergienko R, Sheiner E: Risk factors for early postpartum hemorrhage (PPH) in the first vaginal delivery, and obstetrical outcomes in subsequent pregnancy. J Matern Fetal Neonatal Med 2014, [Epub ahead of print].

26. Sheldon WR, Blum J, Vogel JP, Souza JP, Gulmezoglu AM, Winikoff B, WHO Multicountry Survey on Maternal and Newborn Health Research Network: Postpartum haemorrhage management, risks, and maternal outcomes: findings from the World Health Organization Multicountry Survey on Maternal and Newborn Health. BJOG 2014, 121(Suppl 1):5-13.
27. Treger M, Hallak M, Silberstein T, Friger M, Katz M, Mazor M: Post-term pregnancy: should induction of labor be considered before 42 weeks? J Matern Fetal Neonatal Med 2002, 11:50-53.

28. Wilcox AJ, Skjaerven R: Birth weight and perinatal mortality: the effect of gestational age. Am J Public Health 1992, 82:378-382.

29. Leon DA, Johansson M, Rasmussen F: Gestational age and growth rate of fetal mass are inversely associated with systolic blood pressure in young adults: an epidemiologic study of 165,136 Swedish men aged 18 years. Am J Epidemiol 2000, 152:597-604.

30. Alexander BT: Fetal programming of hypertension. Am J Physiol Regul Integr Comp Physiol 2006, 290:R1-R10.

31. Wild SH, Byrne CD: Evidence for fetal programming of obesity with a focus on putative mechanisms. Nutr Res Rev 2004, 17:153-162.

32. Olsen SF, Osterdal ML, Salvig JD, Kesmodel U, Henriksen TB, Hedegaard M, Secher NJ: Duration of pregnancy in relation to seafood intake during early and mid pregnancy: prospective cohort. Eur J Epidemiol 2006, 21:749-758.

33. Wolfe HM, Zador IE, Gross TL, Martier SS, Sokol RJ: The clinical utility of maternal body mass index in pregnancy. Am J Obstet Gynecol 1991, 164:1306-1310.

34. Stotland NE, Washington AE, Caughey AB: Prepregnancy body mass index and the length of gestation at term. Am J Obstet Gynecol 2007, 197(378):e371-e375.

35. Myklestad K, Vatten LJ, Magnussen EB, Salvesen KA, Romundstad PR: Do parental heights influence pregnancy length?: a population-based prospective study, HUNT 2. BMC Pregnancy Childbirth 2013, 13:33.

36. Caughey $A B$, Stotland NE, Washington $A E$, Escobar GJ: Who is at risk for prolonged and postterm pregnancy? Am J Obstet Gynecol 2009, 200(683):e681-e685

37. Makrides M, Gibson RA, McPhee AJ, Yelland L, Quinlivan J, Ryan P, DOMInO Investigative Team: Effect of DHA supplementation during pregnancy on maternal depression and neurodevelopment of young children: a randomized controlled trial. JAMA 2010, 304:1675-1683.

38. Hertz-Picciotto I, Hopenhayn-Rich C, Golub M, Hooper K: The risks and benefits of taking aspirin during pregnancy. Epidemiol Rev 1990, 12:108-148.

39. CLASP collaborative group: Low dose aspirin in pregnancy and early childhood development: follow up of the collaborative low dose aspirin study in pregnancy. Br J Obstet Gynaecol 1995, 102:861-868.

40. Chaudhari BP, Plunkett J, Ratajczak CK, Shen T, DeFranco EA, Muglia L: The genetics of birth timing: insights into a fundamental component of human development. Clin Genet 2008, 74:493-501.

41. Ley GD: Some aspects of prolonged gestation. Med J Aust 1953, 2:749-752.

42. Ahn MO, Phelan JP: Epidemiologic aspects of the postdate pregnancy. Clin Obstet Gynecol 1989, 32:228-234.

43. Olesen AW, Basso O, Olsen J: Risk of recurrence of prolonged pregnancy. BMJ 2003, 326:476.

44. Morken NH, Melve KK, Skjaerven R: Recurrence of prolonged and post-term gestational age across generations: maternal and paternal contribution. BJOG 2011, 118:1630-1635.

45. Bezold KY, Karjalainen MK, Hallman M, Teramo K, Muglia LJ: The genomics of preterm birth: from animal models to human studies. Genome Med 2013, 5:34.

46. Menon R, Merialdi M, Betran AP, Dolan S, Jiang L, Fortunato SJ, Williams S: Analysis of association between maternal tumor necrosis factor-alpha promoter polymorphism (-308), tumor necrosis factor concentration, and preterm birth. Am J Obstet Gynecol 2006, 195:1240-1248.

47. Uzun A, Laliberte A, Parker J, Andrew C, Winterrowd E, Sharma S, Istrail S, Padbury JF: dbPTB: a database for preterm birth. Database (Oxford) 2012, 2012:bar069.

48. Plunkett J, Doniger S, Orabona G, Morgan T, Haataja R, Hallman M, Puttonen H, Menon R, Kuczynski E, Norwitz E, Snegovskikh V, Palotie A, Peltonen L, Fellman V, DeFranco EA, Chaudhari BP, McGregor TL, McElroy JJ, Oetjens MT, Teramo K, Borecki I, Fay J, Muglia L: An evolutionary genomic approach to identify genes involved in human birth timing. PLOS Genet 2011, 7:e1001365.

49. Wang H, Parry S, Macones G, Sammel MD, Kuivaniemi H, Tromp G, Argyropoulos G, Halder I, Shriver MD, Romero R, Strauss JF 3rd: A functional SNP in the promoter of the SERPINH1 gene increases risk of preterm premature rupture of membranes in African Americans. Proc Natl Acad Sci U S A 2006, 103:13463-13467. 
50. Haataja R, Karjalainen MK, Luukkonen A, Teramo K, Puttonen H, Ojaniemi M, Varilo T, Chaudhari BP, Plunkett J, Murray JC, McCarroll SA, Peltonen L, Muglia L, Palotie A, Hallman M: Mapping a new spontaneous preterm birth susceptibility gene, IGF1R, using linkage, haplotype sharing, and association analysis. PLoS Genet 2011, 7:e1001293.

51. Portela A, Esteller M: Epigenetic modifications and human disease. Nat Biotechnol 2010, 28:1057-1068.

52. Morgan HD, Santos F, Green K, Dean W, Reik W: Epigenetic reprogramming in mammals. Hum Mol Genet 2005, 14(Spec No 1):R47-R58.

53. Jirtle RL, Skinner MK: Environmental epigenomics and disease susceptibility. Nat Rev Genet 2007, 8:253-262.

54. Fraga MF, Ballestar E, Paz MF, Ropero S, Setien F, Ballestar ML, Heine-Suner D, Cigudosa JC, Urioste M, Benitez J, Boix-Chornet M, Sanchez-Aguilera A, Ling C, Carlsson E, Poulsen P, Vaag A, Stephan Z, Spector TD, Wu YZ, Plass C, Esteller M: Epigenetic differences arise during the lifetime of monozygotic twins. Proc Natl Acad Sci U S A 2005, 102:10604-10609.

55. Gluckman PD, Hanson MA, Buklijas T, Low FM, Beedle AS: Epigenetic mechanisms that underpin metabolic and cardiovascular diseases. Nat Rev Endocrinol 2009, 5:401-408.

56. Duque-Guimaraes DE, Ozanne SE: Nutritional programming of insulin resistance: causes and consequences. Trends Endocrinol Metab 2013, 24:525-535.

57. Foley DL, Craig JM, Morley R, Olsson CA, Dwyer T, Smith K, Saffery R: Prospects for epigenetic epidemiology. Am J Epidemiol 2009, 169:389-400.

58. Lillycrop KA, Phillips ES, Jackson AA, Hanson MA, Burdge GC: Dietary protein restriction of pregnant rats induces and folic acid supplementation prevents epigenetic modification of hepatic gene expression in the offspring. J Nutr 2005, 135:1382-1386.

59. Lee H, Jaffe AE, Feinberg Jl, Tryggvadottir R, Brown S, Montano C, Aryee MJ, Irizarry RA, Herbstman J, Witter FR, Goldman LR, Feinberg AP, Fallin MD: DNA methylation shows genome-wide association of NFIX, RAPGEF2 and MSRB3 with gestational age at birth. Int J Epidemiol 2012, 41:188-199.

60. Burris HH, Rifas-Shiman SL, Baccarelli A, Tarantini L, Boeke CE, Kleinman K, Litonjua AA, Rich-Edwards JW, Gillman MW: Associations of LINE-1 DNA Methylation with Preterm Birth in a Prospective Cohort Study. J Dev Orig Health Dis 2012, 3:173-181.

61. Dolan SM, Christiaens I: Genome-wide association studies in preterm birth: implications for the practicing obstetrician-gynaecologist. $B M C$ Pregnancy Childbirth 2013, 13(Suppl 1):S4.

doi:10.1186/1756-0500-7-720

Cite this article as: Schierding et al: Genes and post-term birth: late for delivery. BMC Research Notes 2014 7:720.

\section{Submit your next manuscript to BioMed Central and take full advantage of:}

- Convenient online submission

- Thorough peer review

- No space constraints or color figure charges

- Immediate publication on acceptance

- Inclusion in PubMed, CAS, Scopus and Google Scholar

- Research which is freely available for redistribution 